\title{
ECOLOGICAL FEATURES OF THE FLOWERS OF Aesculus hippocastanum L. AND CHARACTERISTICS OF Aesculus L. POLLEN SEASONS UNDER THE CONDITIONS OF CENTRAL-EASTERN POLAND
}

\author{
${ }^{1}$ Elżbieta Weryszko-Chmielewska, ${ }^{2}$ Maria Tietze, ${ }^{1}$ Magdalena Michońska
}

\author{
${ }^{1}$ Department of Botany, University of Life Sciences in Lublin,ul.Akademicka 15, 20-950 Lublin, Poland \\ ${ }^{2}$ Departmentof Ethology and Technological Basis of Animal Production, University of Life Sciences in Lublin \\ e-mail: elzbieta.weryszko@up.lublin.pl
}

Received: 02.08.2012

\begin{abstract}
The content of Aesculus pollen in aeroplankton of $\mathrm{Lu}-$ blin, located in central-eastern Poland, was studied during the period 2001-2012. The volumetric method was used for the study. The following parameters were determined: start, end, and duration of the pollen season, days of maximum concentration, and total annual pollen counts. Correlation coefficients were calculated between the start of the pollen season and meteorological parameters. The study showed that during the period 2007-2012 the onset of the Aesculus pollen season occurred on average 4 days earlier than in the years 2001-2006. The total annual pollen counts were in the range of 53-271, with an average number of 117 . The average pollen counts did not differ significantly in the first and second year of a 6-year period of the study. The analysis of the correlation coefficients showed that there were significant positive correlations only between the season start date and minimum temperature of the first decade of May. The highest Aesculus pollen concentration occurred between 6 and 22 May. The flowers of A. hippocastanum demonstrate an ambophilous pollination strategy due to partial insect and wind pollination.
\end{abstract}

Key words: aerobiology, Aesculus, pollen seasons, onset, minimum temperature, correlation, ambophilous flowers.

\section{INTRODUCTION}

Aesculus hippocastanum $\mathrm{L}$. is an important ornamental, medicinal, and bee plant. It belongs to relict species of the Tertiary flora and is an endemic species of the Balkan Peninsula (Ć a li ć - D rag os a va c et al. 2010). This tree flowers after 10-15 years and the maximum lifespan of individuals of this species is aro- und 200 years (M a urizi o and Graf1, 1969). The flowers of horse chestnut are zygomorphic and polygamous. They are produced in great numbers in conical panicles 20-30 cm long ( $\mathrm{S}$ e $\mathrm{n}$ e $\mathrm{ta}$ a 2007). The lower part of the inflorescence is occupied by female flowers, the middle one by bisexual ones, while in the upper portion of the inflorescence there are male flowers (Maurizio and Grafl, 1969; Ćalić-Drago$\mathrm{s}$ a v a c et al. 2009). Under Polish conditions, the flowering of A. hippocastanum occurs in May and at the beginning of June (R u t k o w s k i , 2004).

The corolla petals (4-5) are white coloured. At the base of the petals, there are yellow spots that turn red after pollination (Kugle r, 1970; Johns on, 2009).

The flowers of A. hippocastanum are an abundant source of nectar and pollen for insects (M a u r i zio and Graf1,1969; Gúnter, 2007; Li piński, 2010). Bees collect nectar and pollen mainly within the area of large cities where plantings of these trees are most frequently found. These insects form dark red or violet pollen loads from horse chestnut pollen (Maurizio and Grafl, 1969). The pollen of A. hippocastanum is carried not only by insects, but also by the wind. It has been found that the pollen of this species has allergenic properties and may cause pollinosis (S p i e k s m a, 1991).

A. hippocastanum is one of indicator plants whose phenological stages are taken into account in phenological research in different countries of Europe, among others, in Poland (Ni edźw i edź and Jat c z a k, 2008), Austria (K o c h et al. 2008), Germany (Zi m m e r m a n et al. 2008), and Croatia (V u č e t i ć 
et al. 2008). Observations of the blossoming of the first flowers of horse chestnut are carried out, among others, since this marks the full spring period in phenological terms (K r o t o s k a ,1958).

Strong damage caused by the feeding of Cameraria ohridella larvae has been observed in Poland since 1998 ( $\mathrm{Eabanowski}$ and Soika,2003.; We ryszko-Chmielewska and Haraty m, 2011, 2012). Leaf damage can result in poorer flowering and fruiting of horse chestnut trees.

The aim of the present study was to compare the A. hippocastanum pollen seasons over a period of 12 years in order to:

1. Determine the periods of highest risk to allergy sufferers from the pollen of this taxon;

2. Determine whether climate warming affects pollen production and release in the above-mentioned species;

3. Evaluate whether the trees weakened by the feeding of leaf miner larvae during the last few years produce less pollen.

\section{MATERIALS AND METHODS}

The study of the flowers of Aesculus hippocastanum L. and airborne Aesculus pollen content was carried out in Lublin, located in central-east Poland.

5 trees growing in the central part of this city were selected for observation of flowers. The number of flowers and the percentages of 5-petalled and 4-petalled flowers were determined in 10 inflorescences per each tree.

The content of airborne Aesculus pollen was analysed over the period 2001-2012. The investigations were carried out using a standard pollen sampler (VPPS 2000, Lanzoni), which is located in the city centre at a height of $18 \mathrm{~m}$ above ground level on the building of the University of Life Sciences $\left(51^{\circ} 14^{\prime} 37^{\prime} \mathrm{N}\right.$ and $22^{\circ} 32^{\prime} 25^{\prime} \mathrm{E}, 197 \mathrm{~m}$ a.s.l.). The tape in the sampler was changed every 7 days. In a microscopic slide, four longitudinal transects were analysed in which the number of Aesculus pollen grains was determined; this enabled the calculation of the average daily concentration of airborne pollen and subsequently total pollen per $\mathrm{m}^{3}$ of air within a year. The start and end of the pollen season were determined by the $98 \%$ method. The days of maximum pollen concentration were identified in each season.

Several A. hippocastanum trees grew in green spaces near the pollen monitoring site. In the Botanical Garden of the Maria Curie-Skłodowska University, at a distance of $2-3 \mathrm{~km}$, there were few individuals (1-3) of the following other Aesculus species: A. x carnea, A. x hemiacanta, A.x hybrida, A. flava, A. glabra, A. parviflora, A. pavia, and A. turbinata.

Spearman's correlation coefficients were calculated between the pollen season start and maximum, mean, and minimum daily temperature, relative air humidity, and rainfall. Correlations were also determined between the pollen season parameters.

\section{RESULTS}

\section{Characteristics of flowers}

In the panicle-like inflorescences of Aesculus hippocastanum L., numerous scorpioid cymes can be distinguished in which flowers mature from the bottom upwards, which is indicated by the colour of the spots on the petals (Fig. 1A). The number of flowers in the observed inflorescences was 152-184. The perianth consisted of 4-5 sepals and 4-5 petals. It was found that in the inflorescences there was $56 \%$ of four-petalled flowers and $44 \%$ of five-petalled flowers.

The colour attractants in the form of large spots, located on the white petals, were yellow coloured in younger flowers, while in older ones they were pink coloured (Fig. 1B). In the flower, there were 7-8 stamens that differed in length. At the beginning and at the end of flowering, they were bent downwards (Fig.1B,C), whereas during pollen shed they became erect (Fig.1B). At both ends of the anthers, there were red appendages that may perform the role of guides for pollinators (Fig. $1 \mathrm{C}$ ). The horse chestnut pollen released from the anthers was yellow coloured (Fig. 1 D,E). The three-parted pistil was characterized by a superior ovary. The upper part of the style and the stigma were red coloured (Fig. $1 \mathrm{~F}$ ).

\section{Pollen seasons}

Over the study period (2001-2012), the horse chestnut pollen season started on different dates. During the first six years, the onset of the pollen season was observed on 4-10 May, whereas during the next six years the beginning of the season was recorded earlier, i.e. between 28 April and 5 May. The earliest start of the pollen season occurred in 2009 (28 April), while in 2002 the first Aesculus pollen grains were recorded latest (10 May) (Table 1). On average during the period 2007-2012, the pollen season started 4 days earlier (2 May) than in the previous six years (6 May).

The longest season lasted 42 days and was recorded in 2004, whereas the shortest one occurred in 2002 and included 18 days. The average duration of the Aesculus pollen season in Lublin was 28 days. It was noted that in the period 2001-2007 the seasons considerably varied in terms of their duration, while during the next five years (2008-2012) the length of the season was similar (30-33 days) (Table 1).

The values of maximum airborne Aesculus pollen concentrations varied markedly and they ranged 8-44 grains per $1 \mathrm{~m}^{3}$. The highest concentration was recorded in 2001, whereas in the years 2003, 2005, 2010, and 2011 low concentrations were observed (Table 1). 

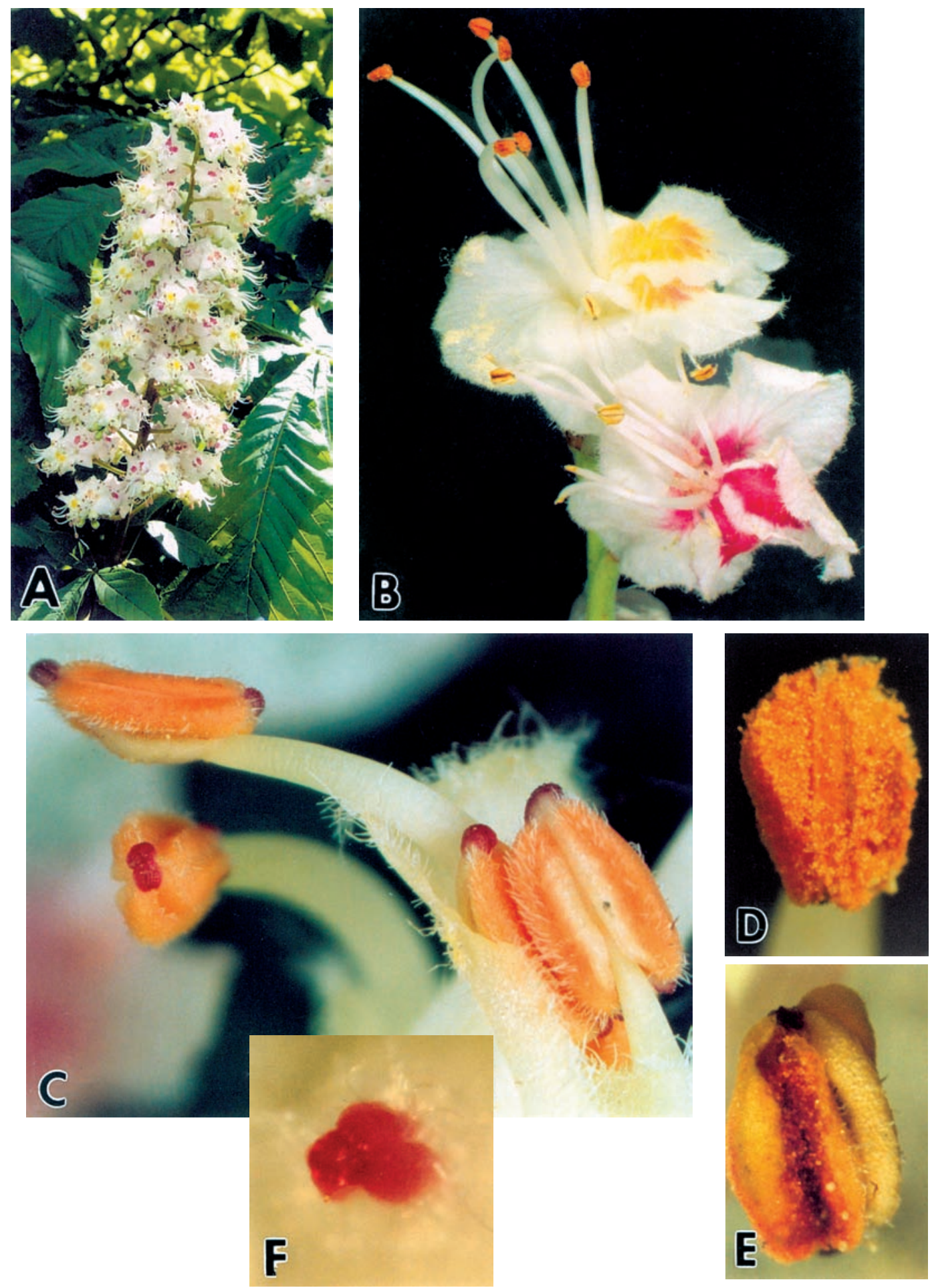

Fig. 1. Flowers of Aesculus hippocastanum and their parts.

A. Inflorescence at full bloom.

B. Horse chestnut flowers at different growth stages:

- the upper flower during pollen release with yellow markings on its petals;

- the lower flower after pollen release with red markings.

C. Part of the androecium of horse chestnut before pollen release. The stamens differ in length and have red appendages guides for pollinators - at both ends of the anthers.

D. Anthers during pollen release.

E. Anthers after most of the pollen has been released.

F. The intensely coloured three-parted stigma of the pistil. 
Table 1

Aerobiological data for Aesculus pollen grains in Lublin during the years 2001-2012

\begin{tabular}{|c|c|c|c|c|c|c|c|c|}
\hline \multicolumn{9}{|c|}{ Pollen season } \\
\hline Year & Start date & $\begin{array}{l}\text { Number of days } \\
\text { from } 1^{\text {st }} \text { January }\end{array}$ & End day & $\begin{array}{l}\text { Number of days } \\
\text { from } 1^{\text {st }} \text { January }\end{array}$ & $\begin{array}{c}\text { Duration } \\
\text { (days) }\end{array}$ & $\begin{array}{c}\text { Peak value } \\
\left(\mathrm{p} / \mathrm{m}^{3}\right)\end{array}$ & $\begin{array}{c}\text { Date of peak } \\
\text { day }\end{array}$ & $\begin{array}{l}\text { Number of days } \\
\text { from } 1^{\text {st }} \text { January }\end{array}$ \\
\hline 2001 & 4.05 & 124 & 25.05 & 145 & 22 & 44 & 8.05 & 128 \\
\hline 2002 & 10.05 & 130 & 28.05 & 148 & 18 & 31 & 10.05 & 130 \\
\hline 2003 & 6.05 & 126 & 24.05 & 144 & 19 & 9 & 9.05 & 129 \\
\hline 2004 & 6.05 & 126 & 16.06 & 167 & 42 & 35 & 6.05 & 126 \\
\hline 2005 & 7.05 & 127 & 8.06 & 159 & 33 & 8 & 22.05 & 142 \\
\hline 2006 & 6.05 & 126 & 29.05 & 149 & 24 & 16 & 16.05 & 136 \\
\hline 2007 & 1.05 & 121 & 25.05 & 145 & 26 & 35 & 15.05 & 135 \\
\hline 2008 & 4.05 & 124 & 4.06 & 155 & 32 & 12 & 18.05 & 138 \\
\hline 2009 & 28.04 & 118 & 28.05 & 148 & 31 & 34 & 10.05 & 130 \\
\hline 2010 & 1.05 & 121 & 30.05 & 150 & 30 & 9 & 10.05 & 130 \\
\hline 2011 & 5.05 & 125 & 6.06 & 157 & 33 & 9 & 13.05 & 133 \\
\hline 2012 & 2.05 & 122 & 2.06 & 153 & 32 & 15 & 11.05 & 131 \\
\hline Mean & 4.05 & 124 & 31.05 & 151 & 28 & 21 & 12.05 & 132 \\
\hline
\end{tabular}

The days with maximum pollen concentration occurred between 6 and 22 May, but during the last four years these dates were closer to each other (10-13 May) (Table 1). In the figure showing the pollen season pattern on the basis of the 12-year means, the maximum concentration of Aesculus pollen is on 12 May. Several peaks can be observed in the pattern of the individual pollen seasons (Fig. 2).

The total annual pollen counts showed large variation between years (Fig. 3). The highest pollen count (271 pollen grains) was recorded in 2001, while the lowest annual pollen totals were observed in 2003 and 2011 (53 grains in both years). The average annual pollen count for the 12-year study period was 117 grains. Similar annual totals were recorded in the first and second year of a 6-year period of the study: 121 and 112 pollen grains. The figure presenting a comparison of the total annual pollen counts throug hout the study period demonstrates that a 3-year cycle of abundant pollen production can be observed in the Aesculus pollen seasons. The years 2007-2009 are an exception, since they do not fit this rule (Fig. 3).

The analysis of Spearman's correlation coefficients between the parameters of the Aesculus pollen season shows that there were significant positive correlations only between the duration of the season and its end date $\left(r_{s}=0.89\right)$ as well as between the maximum pollen concentration and the annual total $\left(r_{s}=0.91\right)$. In the longer seasons, later end dates of the seasons were observed. The occurrence of higher total annual pollen counts was correlated with higher maximum pollen concentrations. This relationship can also be seen when Figures 3 and 4 are compared.

Spearman's correlation coefficients were calculated between the start date of the Aesculus pollen season and meteorological conditions: mean, minimum, and maximum temperature, rainfall, and relative air humidity in the third decade of April and in the first decade of May. The obtained data demonstrate that there were significant positive correlations only between the season start date and minimum temperature of the first decade of May. On the other hand, there was a significant negative correlation between the season start date and humidity in the first decade of May (Table 2). High relative air humidity is not conducive to the onset of the pollen season. The beginning of Aesculus pollen release occurred at an average minimum temperature of $10^{\circ} \mathrm{C}$, while in 2012 it was even $20.7^{\circ} \mathrm{C}$.

The figure illustrating the pollen season dynamics and maximum temperatures during the season shows that abundant pollen production is related to higher maximum temperature (Fig. 5).

Table 2

Spearman's correlation coefficients between the start date of the Aesculus pollen season and meteorological parameters

\begin{tabular}{ccc}
\hline Meteorological parameters & Third decade of April & First decade of May \\
\hline T. $\max .\left({ }^{\circ} \mathrm{C}\right)$ & -0.148 & -0.507 \\
T. min. $\left({ }^{\circ} \mathrm{C}\right)$ & 0.191 & $\mathbf{0 . 6 8 7}$ \\
T. mean $\left({ }^{\circ} \mathrm{C}\right)$ & -0.106 & 0.378 \\
RH $(\%)$ & 0.562 & $\mathbf{- 0 . 6 3 6}$ \\
Rainfall $(\mathrm{mm})$ & 0.403 & -0.182 \\
\hline
\end{tabular}




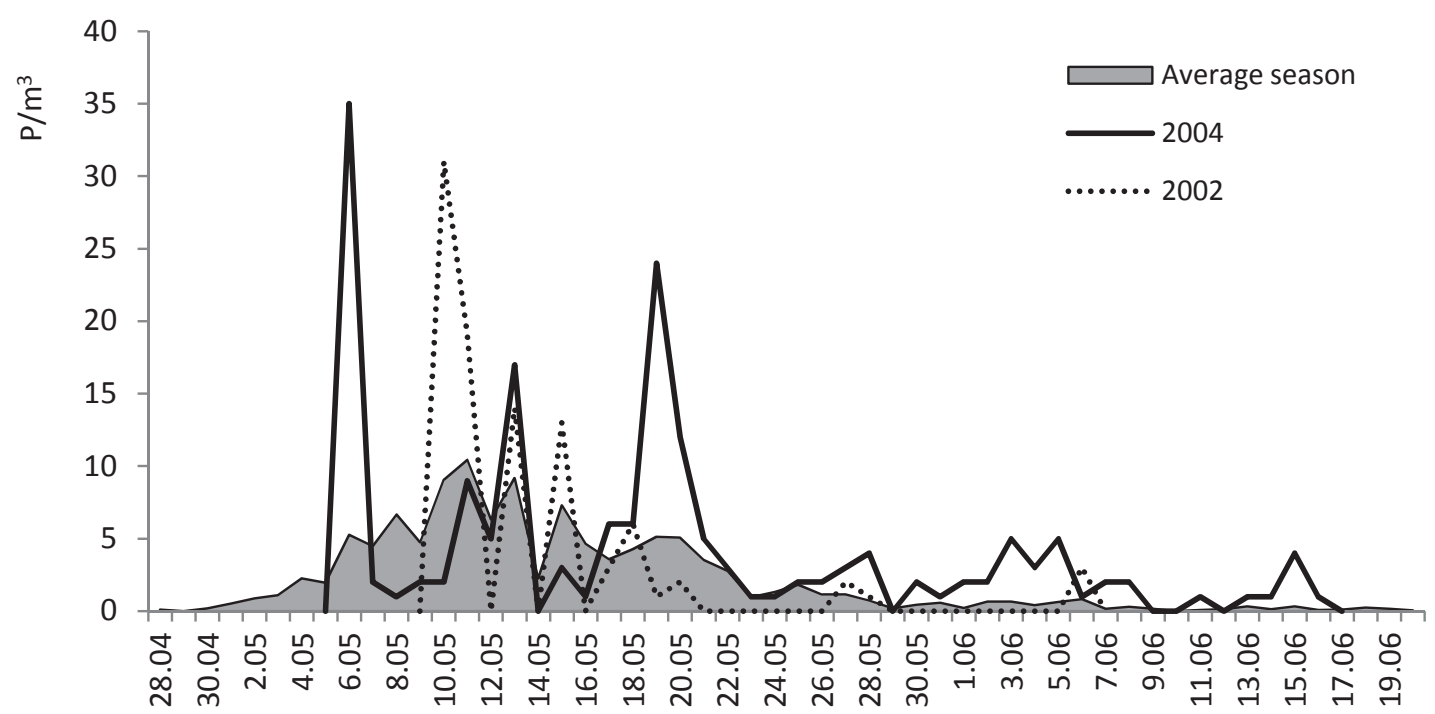

Fig. 2. Dynamics of Aesculus pollen seasons in the years 2002 and 2004 as well as the 12-year mean (2001-2012)

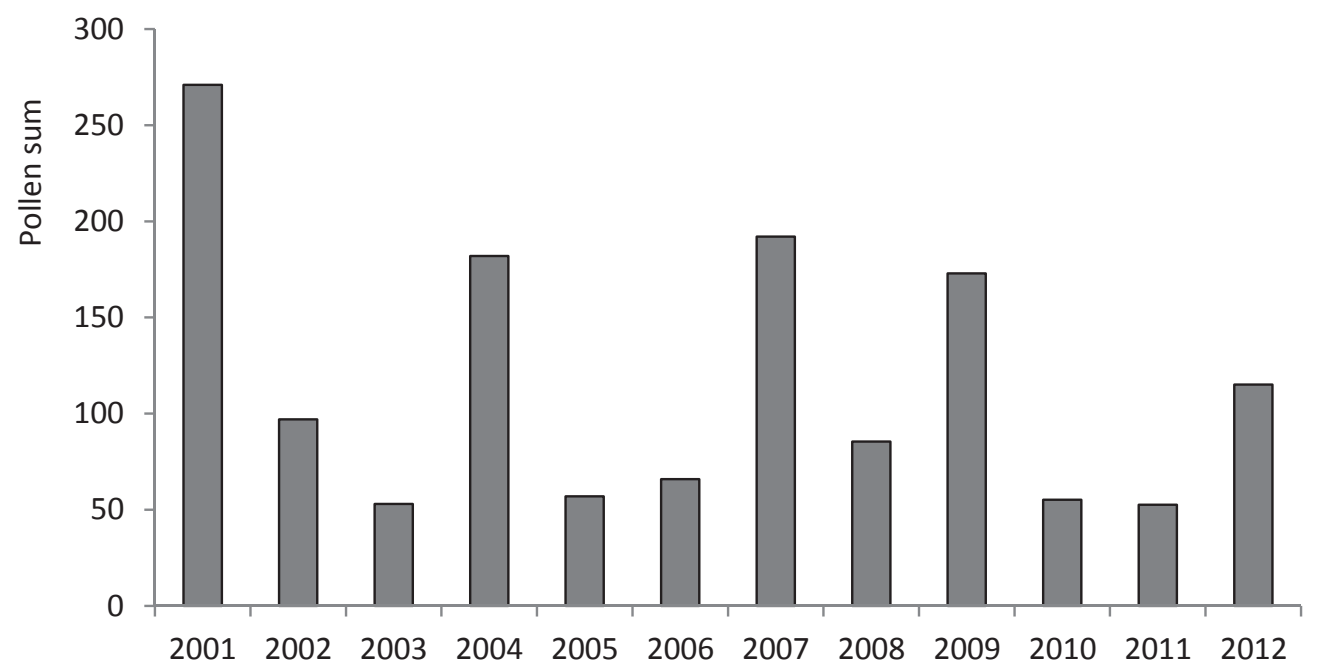

Fig. 3. Annual totals of Aesculus pollen during the study years.

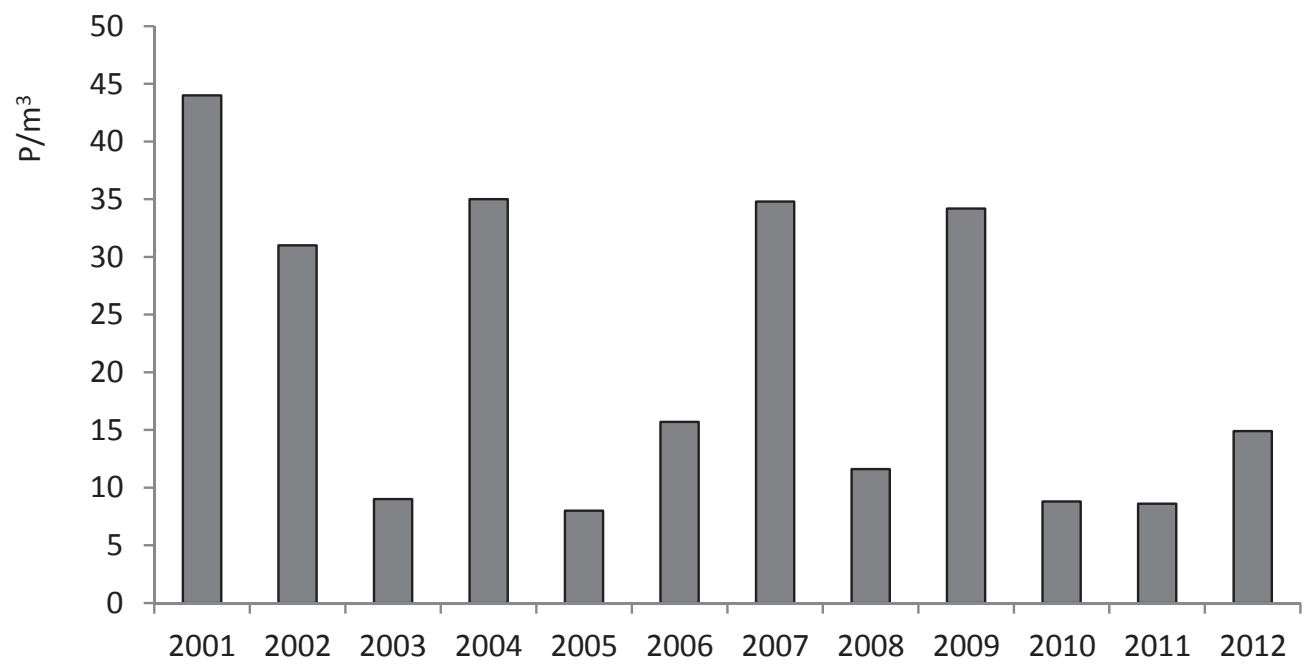

Fig. 4. Comparison of maximum concentrations of Aesculus pollen during the study years. 

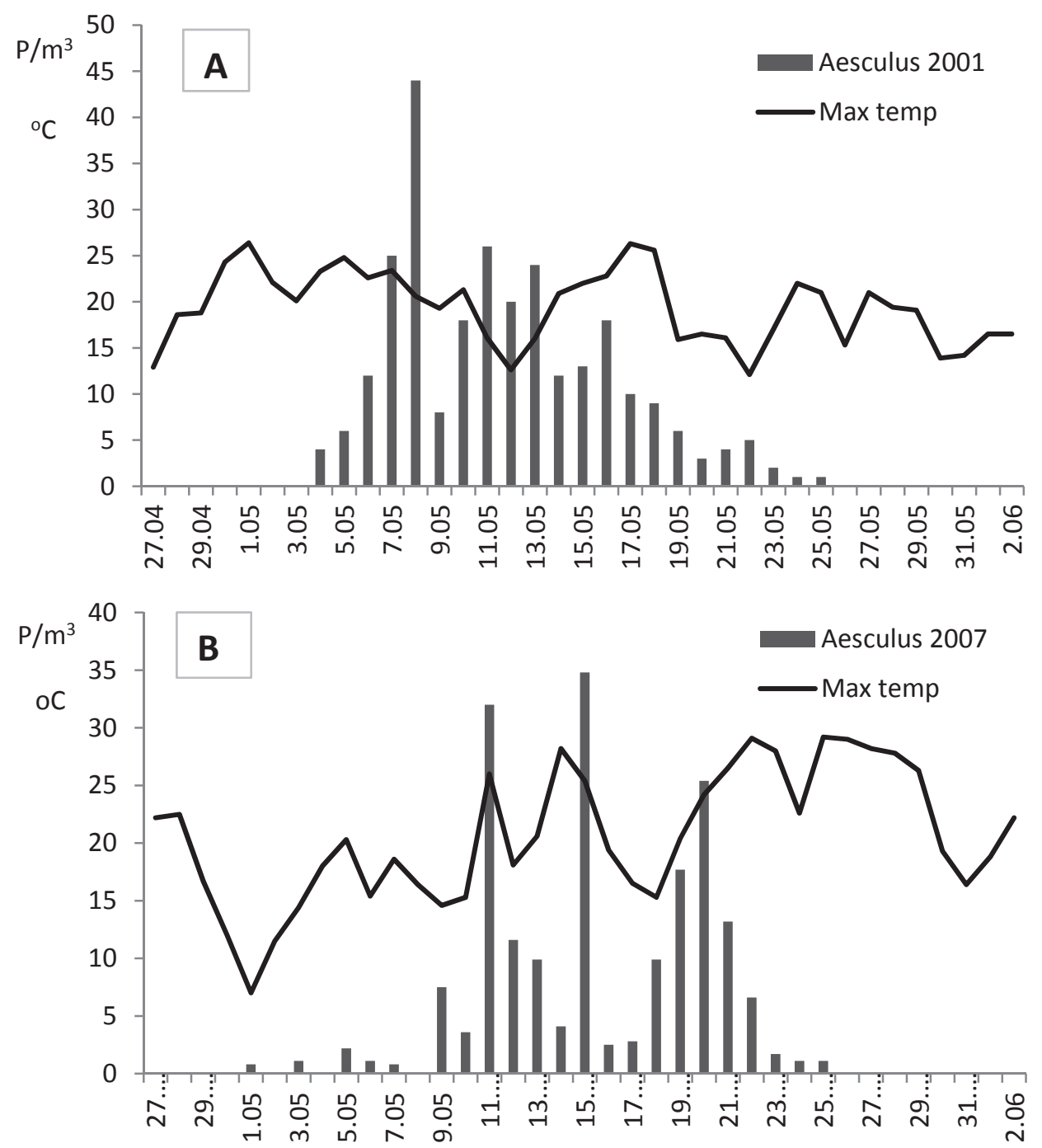

Fig. 5. Dynamics of Aesculus pollen seasons and the curve of maximum temperatures during the season A - 2001; B - 2007.

\section{DISCUSSION}

According to the data collected during our 12-year study period, pollen shed in species of the genus Aesculus most frequently occurs in May, but during the last several years an earlier start of pollen seasons was observed, e.g. in 2009 the first pollen grains of this taxon were recorded within the Lublin area already on 28 April. The study found that in the years 2007-2012 the onset of the Aesculus pollen season occurred on average 4 days earlier than during the period 2001-2006. Because in Lublin the largest number of trees of this genus belongs to the species A. hippocostanum, it can be presumed that the dates of the Aesculus pollen seasons coincide primarily with the flowering of this species.

In phenological observations of flowering of A. hippocastanum in Germany, it has been shown that extreme temperatures occurring in spring during the last years have caused accelerated flowering $(\mathrm{J}$ o c h $\mathrm{n}$ e $\mathrm{r}$ et al. 2011). We have observed that the Aesculus pollen seasons in the years 2008-2012 were slightly longer (30-33 days) than the duration of the medium length seasons (28 days).

The end of the pollen seasons was most frequently observed in May; however, in the last 5 years during the 12-year period of the present study, the last days of the season were in the first or second decade of June. It is possible that the pollen recorded during this time came from flowers of other Aesculus species. The flowering of A. x carnea, among others, falls in May and June (R u t k ow s k i, 2004).

A.hippocastanum produces inflorescences in which very numerous flowers are borne. During our observations, we found that there were 152-184 flowers in a single inflorescence of this species. According to Maurizio and Grafl (1969), one inflorescence of this taxon can produce 100-300 flowers.

Some plant species show an ambophilous pollination strategy in which partial insect and wind pollination can be distinguished (S te lle m a n, 1984). 
A. hippocastanum exhibits the features of an ambophilous species belonging to a plant group in which the entomophilous mode of pollination is dominant. Among the ecological features of this species, typical for entomophily, the following secondary attractants should be mentioned: flower size, colour markings, that is, the contrastingly coloured parts of the petals, stamens and stigma, as well as the scent. However, food attractants, i.e. nectar and pollen, play a more important role for insects. Many publications in the literature show the apicultural importance of horse chestnut nectar and pollen (M a rizio and Graf 1, 1969; Gúnter, 2006; K o ł tow s ki, 2006; Li pińs ki , 2010).

The large number of pollen grains produced by the flower and the constant presence of this taxon's pollen in the air demonstrate that anemophily has some contribution to the system of pollination of A. hippocastanum. One stamen of A. hippocastanum has been found to produce 26,000 pollen grains, one flower 181,000 pollen grains, while a single inflorescence 42 million (K u g le r ,1970). Nevertheless, the content of Aesculus pollen in aeroplankton, recorded in the present study during the 12-year period, shows that only its small portion is dispersed by air currents. Throughout the whole study period, the maximum annual pollen total was 271 grains. Small amounts of atmospheric Aesculus pollen are also recorded in other countries of Europe where A. hippocastanum grows in the wild. In Croatia, the total annual pollen counts for this taxon ranged 27-1094, depending on the region (P e ternel et al. 2003; S te fanic et al. 2007). In Germany the average annual total of Aesculus pollen for a three-year study period was 44 grains ( $\mathrm{M} \mathrm{e} 1 \mathrm{~g}$ a r et al. 2012), while in Italy the average for a 15-year study reached 122 grains (Rizzi-Longo et al. 2010). These data demonstrate that the number of pollen grains per $1 \mathrm{~m}^{3}$ of air within a season is many times lower than the number of pollen grains in one stamen of $A$. hippocastanum.

The pollen of Aesculus shows low allergenic potential (Grant S mith, 1990). Based on our study, it can be stated that the highest pollen concentrations of this taxon occur in the air of Lublin between 6 and 22 May. This 12-year study did not yield results that would entitle us to conclude that the feeding of Cameraria ohridella larvae contributes to the production of lower amounts of pollen by A. hippocastanum trees.

\section{Acknowledgements}

Research supported by the Ministry of Science and Higher Education of Poland as the part of statutory activities of Department of Botany, University of Life Sciences in Lublin.

\section{REFERENCES}

Ćalić-Dragosavac D., Zdravković-Korać S., Miliković D., Radoiević L. 2009. Comparative analysis of microspore size variability in the genus Aesculus (Hippocastanaceae). Arch. Biol. Sci, Belgrade, 61 (4):795-800.

Grant Smith E. 1990. Sampling and Identifying Allergenic Pollens and Molds. Blewstone Press, San Antonio, Teras.

Gúnter P. 2007. Bienenweide. Franckh - Kosmos Verlags$\mathrm{GmbH}$, Stuttgart. (in German)

Jochner S.C., Beck I., Behrendt H., TraidlHoffmann C., Menzel A. 2001. Effects of extreme spring temperatures on urban phenology and pollen production: a case study in Munich and Ingolstadt. Clim. Res. 49: 101-112. http://dx.doi.org/10.3354/ cr01022

Johnson O. 2009. Drzewa. Przewodnik Collinsa, Mulico Oficyna Wydawnicza, Warszawa. (in Polish)

Koch E., Lipa.W, Neumcke R., Zach S. 2008. The history and current status of the Austrian phenology network.[In:]The history and current status of plant phenology in Europe. COST Action 725. COST Office.

Kołtowski Z. 2006. Wielki atlas roślin miododajnych. Przedsiębiorstwo Wydawnicze Rzeczpospolita S.A.(in Polish)

K rotoska T. 1958. Pory roku w życiu roślin. Państwowe Wydawnictwo Naukowe, Poznań.(in Polish)

Kugle r H., 1970. Blútenókologie. G. Fisher Verlang, Stuttgart. (in German)

Li pińs k i M. 2010. Pożytki pszczele. Zapylanie i miododajność roślin. Powszechne Wydawnictwo Rolnicze i Leśne Warszawa, Wydawnictwo Sądecki Bartnik, Stróże. (in Polish)

Łabanowski, Soika G. 2003. Szkodniki ozdobnych drzew liściastych. Plantpress. Kraków.(in Polish)

Maurizio A., Grafl I. 1969. Das Trachtpflanzenbuch. Nektar Und Pollen die wichtigsten Nahrungsquellen der Honingbiene, Ehrenwirth Verlag, München. (in German)

Melgar M., Trigo M.M, Recio M. Docampo S., Gracia-Sanchez J., Cabezudo B. 2012. Atmospheric pollen dynamics in Múnster, North-Western Germany: a three-year study (2004-2006). Aerobiologia, 28: 423-434

Niedźwiedź T., Jatczak K. 2008. History of phenology in Poland..[In:]The history and current status of plant phenology in Europe. COST Action 725. COST Office.

Peternel R., Čulig J., Mitić B., Vukušić J., Šostar Z. 2003. Analysis of airborne concentrations in Zagrel, Croatia, 2002. Ann. Argic. Environ. Med. 10:1007-112.

Razzi-Longo L., Pizzulin-Sauli M., Stravisi F., G a n is P. 2010. Airborne pollen calendar for Trieste (Italy), 1990-2004. Grana, 46(2):98-109. http:// dx.doi.org/10.1080/00173130701302826 
Rutkowski L., 2004. Klucz do oznaczania roślin naczyniowych Polski niżowej. Wydawnictwo Naukowe PWN, Warszawa. (in Polish)

Seneta W., Dolatow ski J.2007. Dendrologia. Państwowe Wydawnictwo Naukowe. Warszawa. (in Polish)

Spieksama F.Th. M. 1991 Regional European pollen calendars. [In:]G. D’Amato, F. Th. M. Spieksma, S. Bonini (eds). Allergenic pollen and pollinosis in Europe, Blackwell Sci Publ., Oxford, London, Edinburgh.

Stefanic E., Rasic S. Merdic S., Colacovic K. 2007. Annual variation of airborne pollen in the city of Vincovci, Northeastern Croatia. Ann. Agric. Environ. Med. 14:97-101.

Stelleman P. 1984. Reflections on the transition from wind pollination to ambophily. Acta Bot. Neerl. 33(4): 497- 508.

Vučetić V., Vučetić M., Lončar Z. 2008. History and present observations in Croatian plant phenology.. [In:]The history and current status of plant phenology in Europe. COST Action 725. COST Office.

Weryszko-Chmielewska E., Haratym W. 2011. Changeas in leaf tissues of common horse chestnut (Aesculus hippocastanum L.) colonised by the horsechestnut leaf miner (Cameraria ohridella Deschaka\&Dymić). Acta Agrobot. 64(4):11-22.

Weryszko-Chmielewska E., Haratym W. 2012. Leaf micromorphology of Aesculus hippocastanum L. and damage caused by leaf - mining larvae of Cameraria ohridella Deschka \& Dymić. Acta Agrobot. 65(3):25-34.

Zimmerman K., Behrendt J., Polte-Rudolf C. 2008. History and current status of German phenology. [In:]The history and current status of plant phenology in Europe. COST Action 725. COST Office.

\section{Cechy ekologiczne kwiatów}

Aesculus hippocastanum L. i charakterystyka sezonów pyłkowych Aesculus L. w warunkach środkowo-wschodniej Polski

Streszczenie

W latach 2001-2012 badano zawartość pyłku Aesculus w aeroplanktonie Lublina, położonego w środkowo-wschodniej Polsce. Do badań wykorzystano metodę wolumetryczną. Określono początek, koniec i długość sezonu pyłkowego, wyznaczono dni maksymalnych koncentracji i sumy roczne ziaren pyłku. Obliczono współczynniki korelacji między początkiem sezonu pyłkowego a parametrami meteorologicznymi. Wykazano, że w latach 2007-2012 początek sezonu pyłkowego Aesculus miał miejsce średnio o 4 dni wcześniej niż w latach 2001-2006. Sumy roczne ziaren pyłku były zawarte w przedziale 53-271, średnio wynosiły 117 . Średnie sumy nie różniły się znacząco w pierwszym i drugim sześcioleciu badań. Analiza współczynników korelacji wykazała, że istotne pozytywne korelacje występowały tylko między datą początku sezonu i temperaturą minimalną pierwszej dekady maja. Największe stężenie pyłku Aesculus występuje między 6 a 22 maja. Kwiaty A. hippocastanum wykazują ambofilną strategię zapylenia ze względu na przeniesienie pyłku przez owady oraz przez wiatr. 